\title{
Accounting
}

\section{Revisiting the determinants of local government performance}

\author{
Frida Magda Sumual ${ }^{a, b *}$, David Paul Elia Saerang ${ }^{a}$, Herman Karamoy and Hendra N. Tawas ${ }^{a}$
}

${ }^{a}$ Faculty of Economics and Business, Universitas Sam Ratulangi, Indonesia

${ }^{b}$ Faculty of Economics and Business, Universitas Negeri Manado, Indonesia

\section{H R O N I C L E}

Article history:

Received: January 12, 2021

Received in revised format:

April 82021

Accepted: April 22, 2021

Available online:

April 22, 2021

Keywords:

Public participation

Internal control system

Financial management transparency

Public accountability

Quality of financial reports

Local government performance

\section{A B S T R A C T}

\begin{abstract}
This present study intends to analyze the factors affecting the performance of the local government of North Sulawesi. The population of this study includes the members of the Regional People's Representative Assembly and the leaders of Regional Apparatus Organizations managing the Regional Revenue and Expenditure Budget (APBD). Those Regional Apparatus Organizations include Education and Culture Office, Health Office, Regional Revenue Service, Tourism Office, Public Works Office, and Auditor Inspectorate of North Sulawesi Province. The sampling technique used is the saturated sampling technique. Data collection techniques employed consist of an interview, documentation study, and questionnaire dissemination. The analysis is conducted using Partial Least Square (PLS). Based on the analysis, we found that public participation has a significant effect on the transparency of financial management; the internal control system has a significant effect on local government performance; the internal control system has a significant effect on public accountability; the internal control system has a significant effect on the quality of financial reports, and public accountability has a significant effect on the performance of local governments. However, public participation has no significant effect on local government performance; public participation has no significant effect on public accountability; public participation has no significant effect on the quality of financial reports; the internal control system has no significant effect on financial management transparency; financial management transparency has no significant effect on local government performance, and the quality of financial reports has no significant effect on local government performance. This study also reveals that public accountability is the mediating variable between the internal control system and local government performance.
\end{abstract}

(C) 2021 by the authors; licensee Growing Science, Canada

\section{Introduction}

All local governments in Indonesia are responsible for conducting good governance (Good Government Governance) in every activity. Every program they run is expected to result in optimum results. A local government is said to have a good performance if it can create social welfare. The local government's performance must be measured, so the public will know how the government carries out its responsibilities. Performance measurement is a systematic process for assessing the planned activity programs, whether they have been appropriately implemented, and whether the government has achieved the set targets. In North Sulawesi (Sulut) Province, which is the object of this study, Manado Municipal Government was the only local government granted a "BB" rating for its Government Agency Performance Accountability System (SAKIP) in 2019. That

* Corresponding author

E-mail address: frida.sumual@gmail.com (F. M. Sumual) 
phenomenon shows that the overall performance of the North Sulawesi Province is still far from the expectation. If that is related to the predicate of compliance in fulfilling public service standards, the Indonesian Ombudsman has designated North Sulawesi as one of the six provinces in Indonesia with low compliance regarding public services. The Indonesian Ombudsman survey in public service standards from May to July 2017 has placed North Sulawesi Province in the red zone category. That phenomenon is inversely proportional to the performance of North Sulawesi Province's financial statements assessed by the Supreme Audit Agency (BPK-RI), which gave an opinion on the 2018 financial statement of North Sulawesi in a WTP (Fair Without Exception) category. Therefore, that mismatch between the opinion of fair without exception and the below-standard implementation of the Government Agency Performance Accountability (AKIP) is an exciting problem to research. The factors affecting that result are worth researching. Generally, several factors affect local government performance, both the financial and non-financial factors. Financial factors include the size of the area (size) proxied by total assets, wealth proxied by Regional Original Income (PAD), intergovernmental revenue proxied by the General Allocation Fund (DAU), and capital expenditure (Nugroho, 2018; Harumiati \& Payamta, 2014; Khasanah \& Rahardjo, 2014; Sudarsana \& Rahardjo, 2013). Furthermore, financial ratios are proxied by the ratio of regional independence, degree of decentralization, and efficiency ratios (Purbasari \& Bawono, 2017, Liu \& Li, 2015; Drew, Kortt, \& Dollery, 2015; Nurdin, Stockdale, \& Scheepers, 2014; Rusmin, Astami, \& Scully, 2014). In comparison, the non-financial factors include public participation (public), internal control system (internal control), transparency of local government management, public accountability, and quality of financial reports.

This present study attempts to make a research hypothesis by utilizing non-financial variables explained by Hoa and Zamor (2017), Raharja et al. (2015), and Achmadi in Sopanah (2010) regarding public participation and local government performance. Afiah and Azwari (2015) and Anisatul et al. (2016) found that internal control significantly affects the financial performance of local governments. Purnama \& Nadirsyah (2016) and Setiyawan \& Safri (2016) stated that local government financial management transparency significantly influences local government performance. Additionally, Purnama and Nadirsyah (2016), Setiyawan and Safri (2016), and Purnama and Nadirsyah (2016) stated that accountability in local government financial management significantly influences local government performance. Besides, Afiah \& Rahmatika (2014), Afiah and Azwari (2015), and Pamungkas (2012) unveiled that the quality of government financial reports directly affects the performance of government institutions. Theoretical literature and several empirical studies also confirmed that those factors affect one another. Kim \& Lee (2017) found that public participation has a positive and significant effect on transparency. Hoa and Zamor (2017) also found a similar result stating that public participation has a positive and significant effect on transparency and accountability. According to agency theory proposed by Jensen and Meckling, as cited by Siagian (2014:10), the government acts as an agent and is responsible for planning and managing the resources properly. The good management of those resources should be written in the regional revenue and expenditure budget and reflected on the financial reports audited by the Financial Audit Board. The quality of local government financial reports, therefore, is influenced by public participation. Afiah \& Rahmatika (2014), Indriasi and Koeswayo (2014), Afiah and Azwari (2015), Agung and Winarningsih (2016), and Silalahi and Sinambela (2017) found that internal control system significantly affects the quality of financial reports. Sari (2012) unveiled that the implementation of internal control significantly influences the transparency of financial reports. Furthermore, Kewo (2017) revealed that the implementation of internal control significantly affects accountability. Based on those explanations, the research model of this study is shown in Fig. 1 as follows.

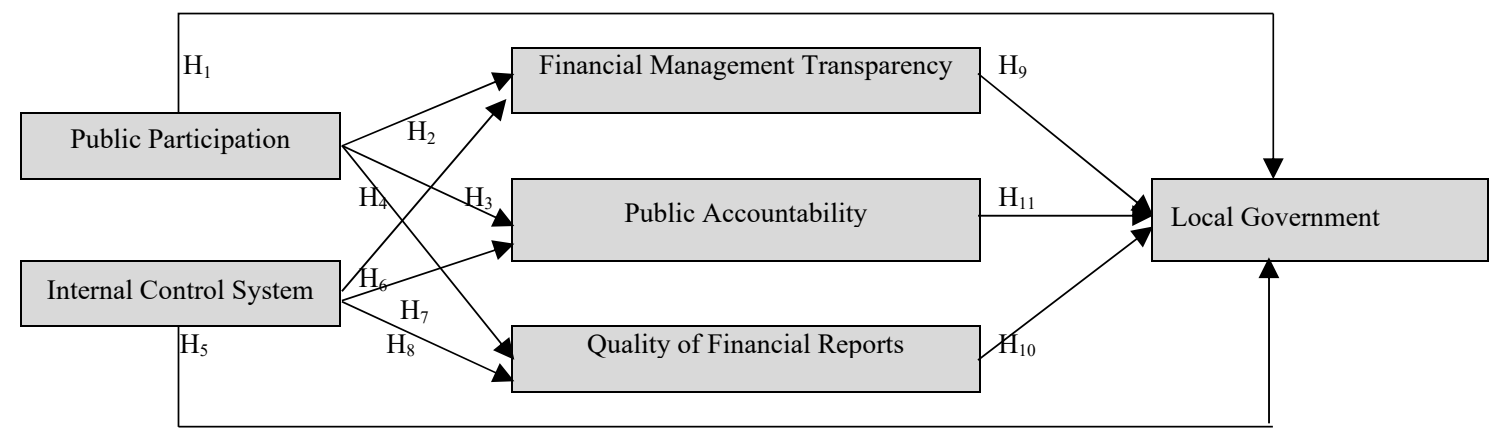

Fig. 1. Research Model

\section{Research Methods}

This study uses a survey method. The object in this study is the provincial government of North Sulawesi with the following analysis units: The offices of Regional People's Representative Assembly (DPRD) and several agencies, namely, the Regional Financial and Asset Management Agency, Education and Culture Office, Health Office, Public Works Office, and Auditor Inspectorate of North Sulawesi Province. The population of this study consists of 107 persons, determined by using the saturated 
sampling technique. Data collection techniques used include an interview, documentation study, and questionnaire dissemination. The analysis is conducted using Partial Least Square (PLS).

\section{Results}

Fig. 2 below portrays the analysis results of the research model.

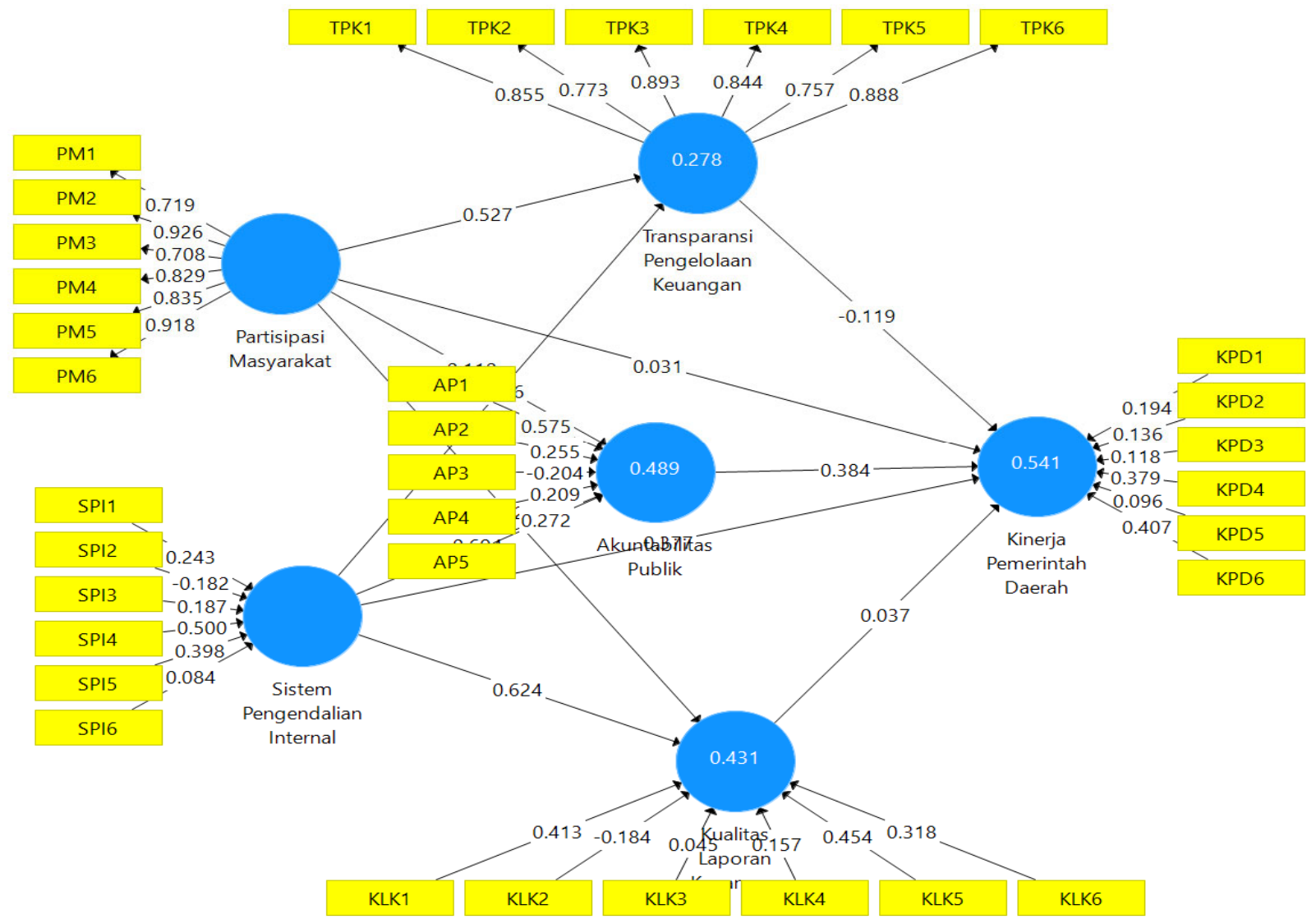

Fig. 2. Analysis Results of Research Model

Based on the analysis results in Fig. 2, the hypothesis test results can be explained in Table 1 as follows.

\section{Table 1}

Hypothesis test results

\begin{tabular}{|c|c|c|c|}
\hline No & Research Hypotheses & Results & Conclusion \\
\hline 1. & Public participation significantly affects government performance. & Coefficient $=0.031$ with the probability $($ p_value $)=0.761$. & Rejected \\
\hline 2. & $\begin{array}{l}\text { Public participation significantly affects the transparency of } \\
\text { financial management. }\end{array}$ & Coefficient $=0.527$ with the probability $\left(p \_\right.$value $)=0.000$. & Accepted \\
\hline 3. & Public participation significantly affects public accountability. & Coefficient $=-0.11$ with the probability $(p$ value $)=0.147$. & Rejected \\
\hline 4. & $\begin{array}{l}\text { Public participation significantly affects the quality of financial } \\
\text { reports. }\end{array}$ & Coefficient $=-0.221$ with the probability $\left(p_{-} v\right.$ value $)=0.052$. & Rejected \\
\hline 5. & $\begin{array}{l}\text { Internal control system significantly affects government } \\
\text { performance. }\end{array}$ & Coefficient $=0.377$ with the probability $\left(p \_v a l u e\right)=0.008$. & Accepted \\
\hline 6. & $\begin{array}{l}\text { Internal control system significantly affects the transparency of } \\
\text { financial management. }\end{array}$ & Coefficient $=0.006$ with the probability $\left(p \_v a l u e\right)=0.953$. & Rejected \\
\hline 7. & Internal control system significantly affects public accountability. & Coefficient $=0.694$ with the probability $(p$ value $)=0.000$. & Accepted \\
\hline 8. & $\begin{array}{l}\text { Internal control system significantly affects the quality of financial } \\
\text { reports. }\end{array}$ & Coefficient $=0.624$ with the probability $\left(p \_\right.$value $)=0.000$ & Accepted \\
\hline 9. & $\begin{array}{l}\text { Transparency of financial management significantly affects } \\
\text { government performance. }\end{array}$ & Coefficient $=-0.19$ with the probability $\left(p_{-}\right.$value $)=0.279$. & Rejected \\
\hline 10. & $\begin{array}{l}\text { Quality of financial reports significantly affects government } \\
\text { performance. }\end{array}$ & Coefficient $=0.037$ with the probability $\left(p \_v a l u e\right)=0.796$. & Rejected \\
\hline 11. & $\begin{array}{l}\text { Public accountability significantly affects government } \\
\text { performance. }\end{array}$ & Coefficient $=0.384$ with the probability $\left(p \_\right.$value $)=0.019$. & Accepted \\
\hline
\end{tabular}




\section{Discussion}

\subsection{Effect of Public Participation on Local Government Performance}

The finding of this study shows that public participation does not significantly affect local government performance. It means the performance of the local government is not influenced by public participation. This result is different from the result of previous studies (Hoa \& Zamor, 2017; Raharja et al., 2015; Sopanah, 2010), stating that public participation significantly affects local government performance.

\subsection{Effect of Public Participation on the Financial Management Transparency}

The finding of this study reveals that public participation significantly affects the local government's financial management transparency. It means the transparency in financial management conducted by the government is affected by public participation. This result is in line with previous studies (Kim \& Lee, 2017; Hoa \& Zamor, 2017).

\subsection{Effect of Public Participation on Public Accountability}

The finding of this study unveils that public participation does not significantly influence public accountability. It means public accountability of the government is not influenced by public participation. This result is not consistent with the previous study conducted by Bastian (2010).

\subsection{Effect of Public Participation on the Quality of Financial Reports}

The finding of this study reveals that public participation does not significantly affect the quality of financial reports. It means the quality of financial reports produced by the government is not influenced by public participation. The preparation of financial reports requires particular knowledge, expertise, and technical skills. The involvement of society in this process, thus, is very minimum. This result is not consistent with previous studies (Utami \& Efrizal, 2013; Rahayu, 2010).

\subsection{Effect of Internal Control System on Local Government Performance}

The finding of this study demonstrates that an internal control system significantly affects local government performance. It means local government performance is substantially affected by the internal control system. The better the internal control system is, the better the local government performance will be. This result supports the previous studies undertaken by Afiah and Azwari (2015) and Anisatul et al. (2016).

\subsection{Effect of Internal Control System on the Financial Management Transparency}

This study's finding presents that an internal control system does not significantly affect financial management transparency. It means the financial management transparency is not merely a result of the prevailed internal control system. This result is not in line with Sari (2012), Winidyaningrum (2009), and Nugraha and Susanti (2010).

\subsection{Effect of Internal Control System on Public Accountability}

The finding of this study reveals that the internal control system significantly affects public accountability of the government. It means public accountability is highly influenced by the internal control system. This result supports the Government Regulation of the Republic of Indonesia Number 60 of 2008 and research by Kewo (2017), stating that the implementation of internal control has a significant effect on local governments' financial accountability.

\subsection{Effect of Internal Control System on the Quality of Financial Reports}

The finding of this study indicates that the internal control system significantly affects the quality of financial reports. It means the quality of the financial reports is greatly influenced by the internal control system. The better the internal control system is, the higher the quality of financial reports produced by the local government will be. This result is consistent with the previous studies (Silalahi \& Sinambela, 2017; Agung \& Winanrningsih, 2016; Afiah \& Azwari, 2015; Afiah \& Rahmatika, 2014; Indriasih \& Koeswayo, 2014). 
The finding of this study indicates that the transparency in financial management does not significantly affect local government performance. It means the performance of the local government is not influenced by the financial management transparency. This result validates previous research conducted (Purnama \& Nadirsyah, 2016; Setiyawan \& Safri, 2016).

\subsection{Quality of Financial Reports on Local Government Performance}

This study's finding exhibits that the quality of financial reports does not significantly affect local government performance. It means local government performance is not solely influenced by the quality of the produced financial reports. This outcome differs from previous studies conducted (Afiah \& Rahmatika, 2014; Afiah \& Azwari, 2015; Pamungkas, 2012).

\subsection{Public Accountability on Local Government Performance}

The result of this study evidences that public accountability significantly affects local government performance. It means local government performance is substantially affected by public accountability. This result supports the result of previous studies conducted by others (e.g. Purnama \& Nadirsyah, 2016; Setiyawan \& Safri, 2016).

\section{Conclusion}

The results of this present study provide a theoretical implication for the accounting literature, primarily in the public sector. Besides, this study's results strengthen the concept of Good Governance, government accounting, Agency Theory, and Stewardship Theory. This study's practical implication implies that the local governments should be more aware of attaining real performance. They must not only pursue the WTP opinion but also perform well. It is even worse if they do that by ignoring the corruption. In Indonesia's democratic system, corruption will create a public preference for not voting the incumbent with poor economic performance.

\section{References}

Afiah, N. N., \& Azwari, P. C. (2015). The effect of the implementation of government internal control system (GICS) on the quality of financial reporting of the local government and its impact on the principles of good governance: A research in district, city, and provincial government in South Sumatera. Procedia-Social and Behavioral Sciences, 211, 811-818.

Afiah, N. N., \& Rahmatika, D. N. (2014). Factors influencing the quality of financial reporting and its implications on good government governance. International Journal of Business, Economics and Law, 5(1), 111-121.

Agung, M., \& Winarningsih, S. (2016). Effect Of Auditor And Internal Control Competence Apparatus For Local Government Quality Of Financial Reporting. European Journal of Accounting, Auditing and Finance Research, 4(7), 113-127.

Anisatul, L., Saptantinah PA, D., \& Harimurti, F. (2017). Pengaruh pengawasan internal, sistem akuntansi keuangan daerah dan pengelolaan keuangan daerah terhadap kinerja keuangan daerah pemerintah kabupaten karanganyar (survey pada dppkad kabupaten karanganyar).

Bastian, I. (2010). Akuntansi Sektor Publik Suatu Pengantar Edisi Ketiga. Jakarta: Erlangga.

Drew, J., Kortt, M., \& Dollery, B. (2015). What determines efficiency in local government? A DEA analysis of NSW local government. Economic Papers: A journal of Applied Economics and Policy, 34(4), 243-256.

Harumiati, Y., \& Payamta, P. (2014). Pengaruh karakteristik pemerintah daerah dan temuan audit BPK terhadap kinerja Pemerintah Daerah Kabupaten/Kota di Indonesia tahun anggaran 2011. Jurnal Akuntansi dan Pendidikan, 3(2), 84-96.

Hoa, T.T.T. \& Zamor, J.C.G. (2017). Citizen Participation in Vietnam's Local Government: Impact on Transparency and Accountability. Journal of Public Administration and Governance, 7(4).

Indriasih, D., \& Koeswayo, P. S. (2014). The effect of government apparatus competence and the effectiveness of government internal control toward the quality of financial reporting in local government. Research Journal of Finance and Accounting, 5(20), 38-47.

Khasanah, N. L., \& Rahardjo, S. N. (2014). Pengaruh karakteristik, kompleksitas, dan temuan audit terhadap tingkat pengungkapan laporan keuangan pemerintah daerah. Diponegoro Journal of Accounting, 3(3), 1-11.

Kewo, C. L. (2017). The influence of internal control implementation and managerial performance on financial accountability local government in indonesia. International Journal of Economics and Financial Issues, 7(1), 293-297.

Kim, S., \& Lee, J. (2017). Citizen Participation and Transparency in Local Government:Do Participation Channels and Policy Making Phases Matter? Proceedings of the 50th Hawaii International Conference on System Sciences. URI: http://hdl.handle.net/10125/41487.

Liu, H., \& Li, X. (2015). Government Decentralisation and Corporate Fraud: Enterprises in China. China Journal of Accounting Studies, 3(4), 320(4). 
Nugraha, D. S., \& Susanti, A. (2010). The influence of internal control system to the reliability of local government financial statement (Case study at Pemerintah Provinsi Jawa barat). Jurnal Ekonomi, Keuangan, Perbankan, dan Akuntansi, 2(2), $259-280$.

Nugroho, T. R. (2018). Pengaruh Karakteristik Pemerintah Daerah Terhadap Kinerja Keuangan Pemerintah Daerah Kabupaten \&amp; Kota Di Jawa Timur. Jurnal Akuntansi Dan Pendidikan, 7(1), 27.

Nurdin, Stockdale, R., \& Scheepers, H. (2014). Coordination and Cooperation in Ein Ein Ecal Ecal Ecal E. The Electronic Journal of Information Systems in Developing Countries, 61(1).

Pamungkas, B. (2012). Pengaruh penerapan akuntansi sektor publik dan pengawasan terhadap kualitas laporan keuangan dan implikasinya terhadap akuntabilitas kinerja instansi pemerintah. Jurnal Ilmiah Ranggagading, 12(2), 82-93.

Purbasari, H., \& Bawono, A. D. B. (2017). Pengaruh Desentralisasi Fiskal, Sistem Pengendalian Internal dan Kinerja Pemerintah Daerah Terhadap Akuntabilitas Laporan Keuangan. Riset Akuntansi dan Keuangan Indonesia, 2(2), $102-108$.

Purnama, F., \& Nadirsyah. (2016). Pengaruh Pengawasan Keuangan Daerah, Akuntabilitas, dan Transparansi Pengelolaan Keuangan Daerah terhadap Kinerja Pemerintah Daerah Pada Kabupaten Aceh Barat Daya. Jurnal Akuntansi Trisakti, 7(2), 231-246.

Raharja, G. P., Herawati, N. T., AK, S., \& Purnamawati, I. G. A. (2015). Pengaruh Akuntabilitas, Partisipasi Masyarakat dan Pengawasan Internal terhadap Kinerja Organisasi (Pada Dinas Pekerjaan Umum Kabupaten Buleleng). JIMAT (Jurnal Ilmiah Mahasiswa Akuntansi) Undiksha, 3(1).

Rahayu, S. (2010). Persepsi pemerintah daerah kota Jambi terhadap partisipasi masyarakat dan transparansi kebijakan publik dalam penyusunan anggaran pendapatan dan belanja daerah. Jurnal Penelitian Universitas Jambi: Seri Humaniora, 12(2), 43402.

Rusmin, R., Astami, E. W., \& Scully, G. (2014). Local government units in Indonesia: demographic attributes and differences in financial condition. Australasian Accounting, Business and Finance Journal, 8(2), 88-109.

Sari, D. (2012). Pengaruh pengendalian internal terhadap transparansi laporan keuangan Pemerintah Daerah.

Setiawan, H. E., \& Safri, M. (2016). Analisis Pengaruh Akuntabilitas Publik, Transparansi Publik dan Pengawasan Terhadap Kinerja Satuan Kerja Perangkat Daerah di Kabupaten Bungo. Jurnal Perspektif Pembiayaan dan Pembangunan Daerah, 4(1), 51-72.

Siagian, S. P. (2014). Manajemen Sumber Daya Manusia Bumi Aksara. Jakarta.

Silalahi, T., \& Sinambela, S. (2017). Determinants Of Financial Report Accountability, And It's Implication on Financial Report Quality: An Empirical Study Of Fiancial Report Statement In North Sumatera Province, Indonesia. International Journal of Economics, Commerce and Management, 5(3).

Sopanah, S. (2010). Studi Fenomenologis: Menguak Partisipasi Masyarakat Dalam Proses Penyusunan APBD. Jurnal Akuntansi Dan Auditing Indonesia, 14(1).

Sudarsana, H. S., \& Rahardjo, S. N. (2013). Pengaruh karakteristik pemerintah daerah dan temuan audit BPK terhadap kinerja pemerintah daerah (Studi pada pemerintah kabupaten/kota di Indonesia) (Doctoral dissertation, Fakultas Ekonomika dan Bisnis).

Transparency International Indonesia. (2015). Survei Persepsi Korupsi. https://inovasi.lan.go.id/uploads/download/1458245917 IPK 2015 LAPORAN AKHIR fin_2.pdf.

Utami, K., \& Efrizal, S. (2013). Pengaruh Pengetahuan Dewan Tentang Anggaran Terhadap Pengawasan Keuangan Daerah Dengan Variabel Pemoderasi Partisipasi Masyarakat Dan Transparansi Kebijakan Publik. Jurnal WRA, 1(1).

Winidyaningrum, C. (2009). Pengaruh Sumber Daya Manusia Dan Pemanfaatan Teknologi Informasi Terhadap Keterandalan Dan Ketepatwaktuan Pelaporan Keuangan Pemerintah Daerah Dengan Variabel Intervening Pengendalian Intern Akuntansi (Studi Empiris di Pemda subosukawonosraten) (Doctoral dissertation, UNS (Sebelas Maret University)).

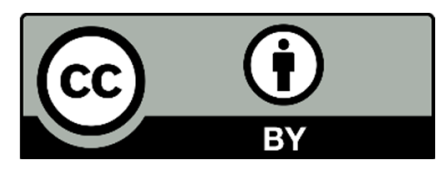

(C) 2021 by the authors; licensee Growing Science, Canada. This is an open access article distributed under the terms and conditions of the Creative Commons Attribution (CC-BY). license (http://creativecommons.org/licenses/by/4.0/). 